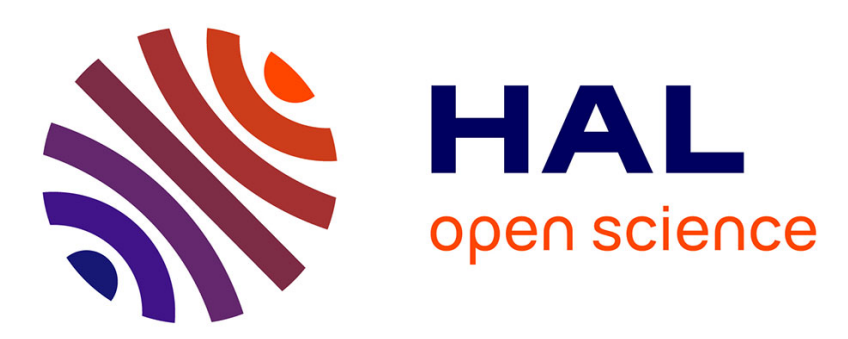

\title{
First paleomagnetism of Eocene rocks from Gargano: widespread overprint or non rotation?
}

\author{
F. Speranza, C. Kissel
}

\section{To cite this version:}

F. Speranza, C. Kissel. First paleomagnetism of Eocene rocks from Gargano: widespread overprint or non rotation?. Geophysical Research Letters, 1993, 20 (23), pp.2627-2630. 10.1029/93GL02816 . hal-03587227

\section{HAL Id: hal-03587227 \\ https://hal.science/hal-03587227}

Submitted on 24 Feb 2022

HAL is a multi-disciplinary open access archive for the deposit and dissemination of scientific research documents, whether they are published or not. The documents may come from teaching and research institutions in France or abroad, or from public or private research centers.
L'archive ouverte pluridisciplinaire HAL, est destinée au dépôt et à la diffusion de documents scientifiques de niveau recherche, publiés ou non, émanant des établissements d'enseignement et de recherche français ou étrangers, des laboratoires publics ou privés. 


\title{
FIRST PALEOMAGNETISM OF EOCENE ROCKS FROM GARGANO: WIDESPREAD OVERPRINT OR NON ROTATION?
}

\author{
F. Speranza and C. Kissel
}

Centre des Faibles Radioactivités, Laboratoire mixte CNRS/CEA, Gif-sur-Yvette, France.

\begin{abstract}
A paleomagnetic study was carried out in the Gargano Peninsula on 37 sites (500 cores) of mainly Eocene age. Eight normal polarity directions can be interpreted either in terms of remagnetization, or of a small post Middle-Eocene counterclockwise rotation of Adriatic foreland with respect to stable Africa. The reverse directions seem to result from a widespread remagnetization.
\end{abstract}

\section{Introduction}

The reconstruction of the geodynamical evolution of the Mediterranean Alpine belt as a result of the African-European convergent movements has been a matter of debate among scientists. The whole framework is strongly complicated by the succession of rectilinear orogens formed at different times, arcs and back-arc basins related to different subduction planes [see e.g. Ricou et al., 1986]. In this context, paleomagnetic studies are critical to define the rotational evolution of the different units that form the Mediterranean Alpine belt.

One of the main features of the Central Mediterranean area is a rigid block of continental crust called the Adriatic Platform or "Adria" [Channell et al., 1979]. Different sedimentological and paleomagnetic studies have shown that "Adria" belonged to the southern Tethyan domain during Mesozoic times. The late Cretaceous-Cenozoic collision between Europe and Adria, as part of the African plate, gave rise to the complex periadriatic orogen. Several paleomagnetic studies have shown that the Adriatic platform has undergone an additional post-Cretaceous counterclockwise rotation of about $17^{\circ}$ with respect to Africa [see Lowrie, 1986]. Recently, Scheepers [1992] has shown that no significant rotation occurred during Pleistocene time. The rarity of suitable outcropping Cenozoic rocks in the Apulian foreland did not allow so far to better constrain the rotation in time between the Upper Cretaceous and the Pleistocene. The only available Cenozoic data, obtained from the southernmost part of Adria, indicate a possible post-Oligocene $25^{\circ}$ clockwise rotation of this area [Tozzi et al., 1988]. However, the in-situ $\mathrm{N}-\mathrm{S}$ directions and the fact that no tilt test could be applied to these data did not allow to exclude a possible remagnetization.

In this paper we report on paleomagnetic results obtained mainly from Eocene limestones from the Gargano Peninsula where some of the Cretaceous poles of Adria have been obtained [Channell, 1977, VandenBerg, 1983].

\section{Copyright 1993 by the American Geophysical Union.}

\section{Geological Setting and Sampling.}

The Gargano promontory is one of the few emerged parts of the non-deformed Adriatic plate. Several geophysical and geochemical data suggest that Gargano is an anomalous part of the Adriatic foreland: it is a structural and topographic high (1000 $\mathrm{m}$ of altitude in the central part), with a relatively thin continental crust $(25 \mathrm{~km})$, elevated heat flow and rise of gas possibly coming from sub-crustal sources [Funiciello et al., 1988]. Apart from Triassic dolomites and evaporites reached in bore-holes, the thick Jurassic-Cretaceous sequence of Gargano is composed of shelf limestones in the southwestern part that become gradually pelagic northeastward. The available Cretaceous paleomagnetic data were obtained from these cherty limestones [Channell, 1977, VandenBerg, 1983]. The southern part of the peninsula is cut by an important E-W crustal discontinuity with recent strike-slip activity (the Mattinata fault) [Funiciello et al., 1988].

The majority of our paleomagnetic sites (25 out of 37) has been collected in the Middle-Eocene shelf limestones between Peschici and Vieste (Figure 1B). This formation is transgressive on Upper Cretaceous limestones. In this area we also collected two sites in Upper Cretaceous pelagic limestones. Other 8 sites were sampled south of the Mattinata fault (Figure 1C), in the Lower Eocene shelf limestones that are much more porous and lighter than in the northern zone. Finally we sampled one site in an Eocene doleritic dyke (Pietre Nere, Figure 1A) located on the northwestern coast of Gargano, and one site in the Triassic limestones thermometamorphosed by this dyke.

In each site 8 to 20 cores (12-13 as an average) were drilled using standard paleomagnetic techniques. These cores, each of them giving 2 to 5 standard specimens, are well distributed both horizontally over 10 to 20 meters and vertically over 5 to 10 different beds.

\section{Magnetic Mineralogy}

For at least one specimen per site we tried to characterize the nature of the magnetic carriers using both their coercivity and their thermal spectra. For the strongly magnetized sites from Pietre Nere (GA01, GA02), we analysed both the hysteresis loops with an alternating gradient force magnetometer (Micromag 2900) and the thermomagnetic curves with an horizontal Curie Balance. A coercive force of about 0.5T and a Curie temperature of $350^{\circ} \mathrm{C}$ suggest the presence of iron sulphides in the site GA01, while in the dyke (GA02) the same parameters $\left(0.3 \mathrm{~T}\right.$ and $\left.580^{\circ} \mathrm{C}\right)$ are typical for magnetite.

For all the other sites, the stepwise acquisition of the isothermal remanent magnetization (IRM) and the remanent coercivity (Hcr) have been determined. We also thermally demagnetized the samples previously saturated in high (2.7T), intermediate (0.5T), and low (0.05T) magnetic fields along the three sample axes following the method given by 


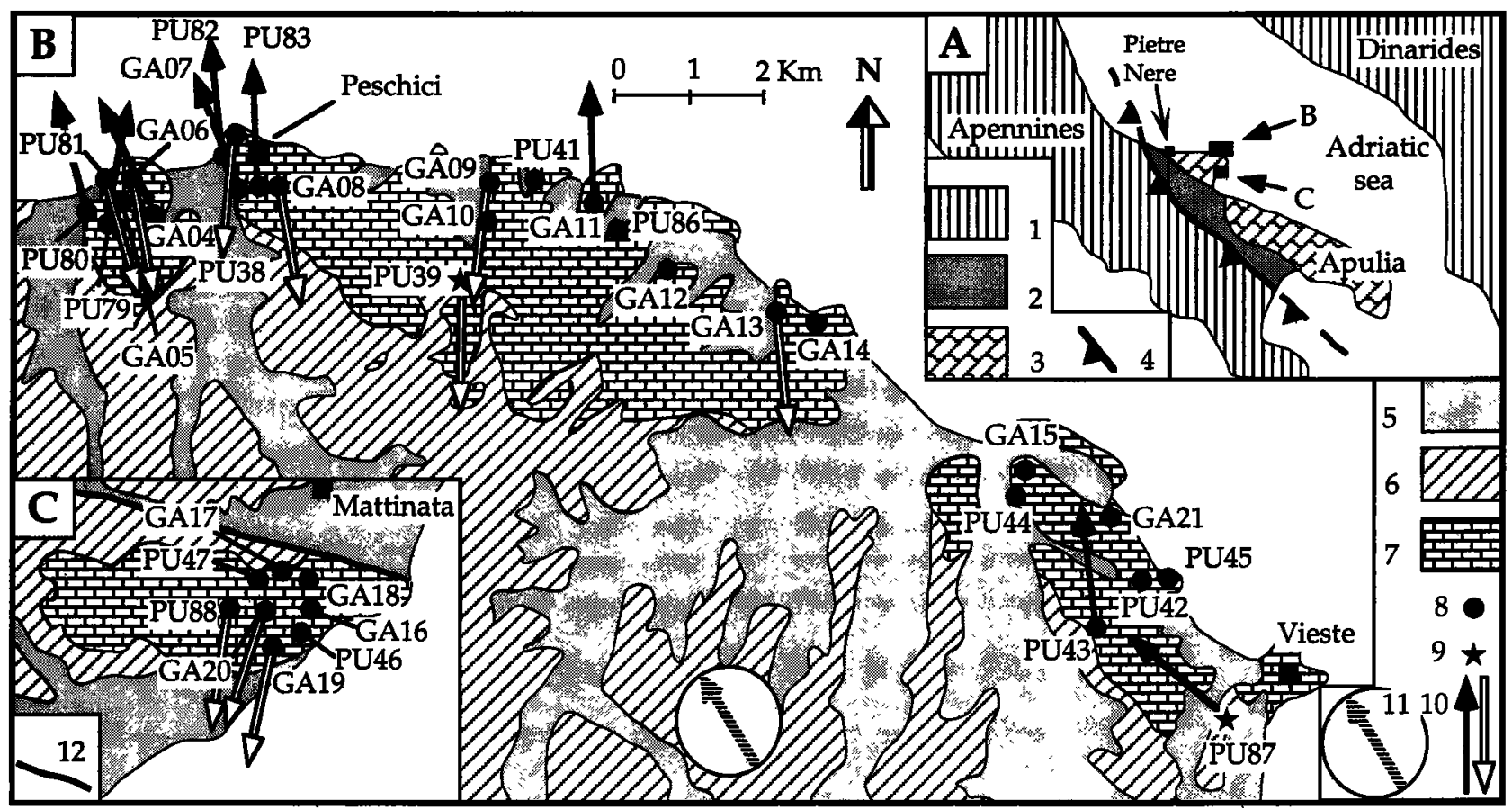

Fig. 1. A: Schematic map of southern Adriatic and surrounding areas (1: Periadriatic orogens; 2: Bradanic foredeep; 3: Adriatic foreland; 4: Front of the Apenninic nappes) B and C: Geological schemes of the two sampled zones in the Gargano Peninsula (5: Recent deposits; 6: Upper Cretaceous limestones; 7: Eocene limestones; 8: Eocene paleomagnetic sites: 9: Upper Cretaceous paleomagnetic site; 10: Paleodeclinations after bedding correction (black and white arrows: normal and reversed directions respectively); 11: Mean Upper Cretaceous paleodeclinations [VandenBerg, 1983]; 12: Mattinata fault.

Lowrie [1990]. These measurements were made with a 2G 3axes cryogenic magnetometer in a shielded room.

In about $60 \%$ of the studied sites from the northern zone (Figure 1B), the total saturation is acquired between 0.2 and $0.3 \mathrm{~T}$, and the $\mathrm{Hcr}$ values varies between 30 and $60 \mathrm{mT}$. Thermal demagnetization of the three orthogonal components of IRM confirms that the high coercivity component is not significant, and that the contribution of both intermediate $(0.5 \mathrm{~T})$ and low $(0.05 \mathrm{~T})$ coercivity minerals is progressively removed up to a temperature between 500 and $600^{\circ} \mathrm{C}$ (Figure 2a). In those sites, the main magnetic carriers are thus low Ticontent magnetites. In the rest of the samples from the northern zone the IRM acquisition analysis reveals the coexistence of low coercivity fraction saturating around $0.3 \mathrm{~T}$, and of high coercivity minerals generally not yet saturated at the maximum achievable field (2.7T). The high coercivity component is mainly carried by goethite (unblocked before $120^{\circ} \mathrm{C}$ ) and to a lesser extent by hematite (Figure $2 \mathrm{~b}$ ). In such samples, the soft fraction corresponds to magnetite, and both low and high coercivities contribute to the intermediate component. In summary, in the northern part of the studied area, in addition to low Ti-content magnetites other magnetic carriers such as goethite, hematite and iron sulphides can be associated, in some proportions greatly varying from site to site. No stratigraphical or geographical systematic recurrence of those magnetic mineral associations has been observed, but the total quantity of ferromagnetic minerals (intensity of NKM and saturated IRM) is much higher in the northwestern area, around Peschici village.

The same analyses performed on the samples coming from the southern area (Figure 1C) show that in all the sites except one (GA19) the only magnetic carrier is magnetite. In the site GA19 the saturation of IRM is reached at only $1 T$, the remanent coercivity is as high as $240 \mathrm{mT}$, and both the high and the intermediate coercivity components are demagnetized at $620^{\circ} \mathrm{C}$, the soft component being negligeable: the hematite is thus the predominant ferromagnetic mineral.

\section{Paleomagnetic Results}

NRM stability of every single sample was investigated by stepwise thermal demagnetization. The low field susceptibility was also measured at each step of the demagnetization in order to monitor eventual major changes in the magnetic minerals during the heating.

About $62 \%$ of the Eocene samples revealed a very weak magnetization (about 5.10-6 A/m) and they could not be measured accurately even using a cryogenic magnetometer.

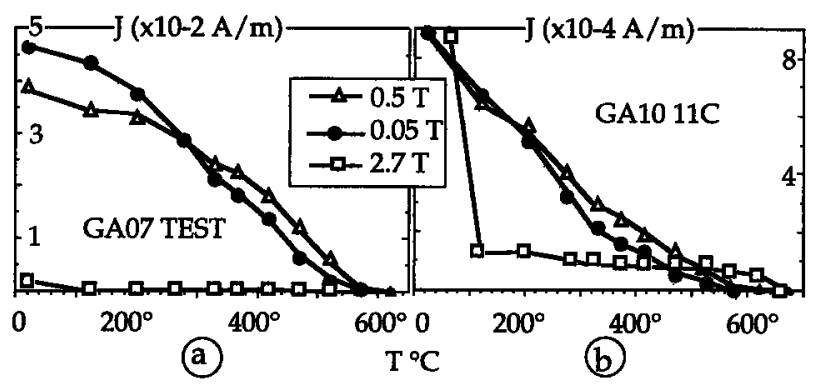

Fig. 2. Thermal demagnetization of a three-component IRM produced by magnetizing the samples in $2.7,0.5$ and $0.05 \mathrm{~T}$ sucessively along the three different samples axes. 


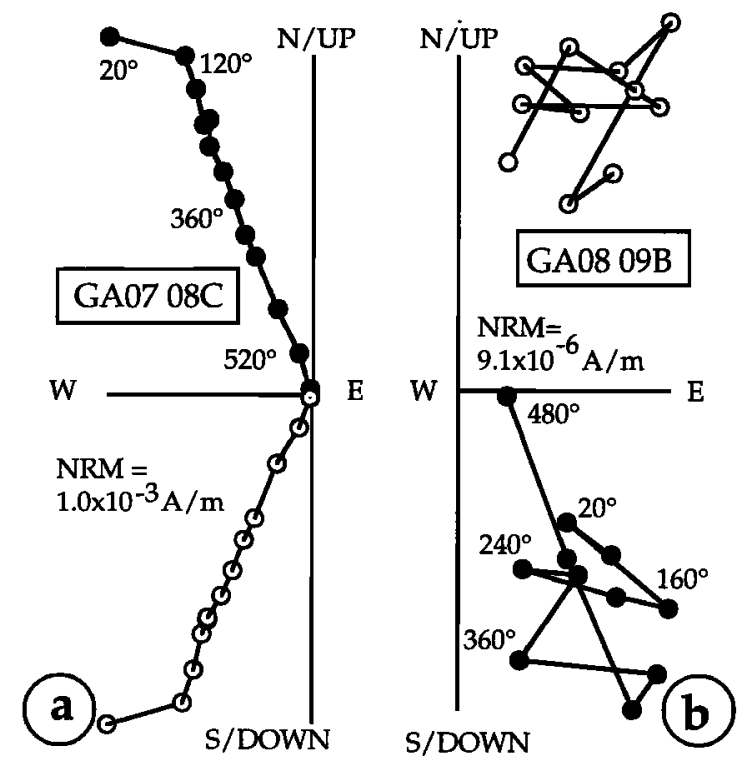

Fig. 3. Typical thermal demagnetization diagrams $(\bullet, O$ : projections onto the horizontal and the vertical planes respectively) of two Middle-Eocene limestone samples.

All the other samples ( 17 sites), were demagnetized in 8 to 13 steps between room temperature and the limit of reproducible results $\left(350\right.$ to $\left.600^{\circ} \mathrm{C}\right)$. For the Pietre Nere sites and for some well magnetized limestone samples (about $28 \%$ ), apart from a small viscous component removed below $200-250^{\circ} \mathrm{C}$, orthogonal demagnetization diagrams isolate a single stable component of magnetization (Figure 3a). The other weakly magnetized Eocene samples $\left(10^{-5} \mathrm{~A} / \mathrm{m}\right)$, do not show any significant decrease of the intensity between $20^{\circ} \mathrm{C}$ and $400^{\circ}$ to $500^{\circ} \mathrm{C}$. In the same time, the direction, even not very well defined for this range of intensities, does not change drastically. This direction has been considered as the stable one (Figure 3b). Only in a few samples demagnetization data fit on great circles. Site-mean directions, obtained using Fisher's statistics [1953] or the method given by McFadden and McElhinny [1988] are reported in Table 1.

The mean paleomagnetic directions obtained from sites GA01 and GA02 (Pietre Nere) are very well defined. Unfortunately, one of them is aberrant $\left(\mathrm{I}=75^{\circ}\right)$ and moreover, they are completely different from each other. This unconsistency is not understood. The mean directions obtained from the two Upper Cretaceous sites (PU39 and PU87) are much more scattered than the data previously obtained by the other authors [Channell, 1977, VandenBerg, 1983] and thus they do not bring any further information.

The majority of our data have been obtained from the Eocene limestones both in the northern and in the southern part of the Gargano. The three measurable Lower Eocene sites sampled in the southern part have reverse polarity (GA19, GA20, PU88, Table 1 and Figure 1). The mean direction obtained from these sites before bedding correction $\left(\mathrm{D}=180^{\circ} \mathrm{I}=-60^{\circ}\right)$ is similar to the direction generated by a recent reverse geocentric axial dipole field at the Gargano latitude $\left(\mathrm{D}=180^{\circ}, \mathrm{I}=-61^{\circ}\right)$. The mean direction after tilt correction $\left(\mathrm{D}=192^{\circ} \mathrm{I}=-65^{\circ}\right)$ has an inclination value that is about $20^{\circ}$ greater than the Lower Eocene expected one $\left(\mathrm{I}=48^{\circ}\right)$ for the Adriatic plate, as a part of the African plate [Besse and
Courtillot, 1991]. These results seem to prove that these porous sediments have been remagnetized during a recent reverse period. This might happen during the activity of the Mattinata fault, which is thought to be recent [Funiciello et al., 1988]. We point out that the remagnetization occurred although 2 out of 3 sites are characterized by only magnetite as the main magnetic carrier, as already observed in Paleozoic rocks [McCabe et al., 1983].

As far as the Middle Eocene formations of the PeschiciVieste area are concerned, both reverse and normal directions have been observed. When the reverse ones are inverted through the origin, the mean regional paleomagnetic direction is defined by $\mathrm{N}=14 ; \mathrm{D}=355^{\circ} ; \mathrm{I}=56^{\circ} ; \mathrm{K}=27 ; \alpha_{95}=7.8$ before bedding correction, and $\mathrm{N}=14 ; \mathrm{D}=352^{\circ} ; \mathrm{I}=47^{\circ} ; \mathrm{K}=57.6$; $\alpha_{95}=5.3$ after bedding correction (Figure 4 , Table 1 ).

\section{Discussion}

The question arises whether these data can be interpreted in terms of post-Eocene tectonic rotations of the Adriatic plate, or they are simply due to recent remagnetization, as shown for the southern sampled area. From Figure 4 it is clear that before tilt correction 5 out of 6 reverse directions are grouped very close to the field produced by a recent reverse geocentric axial dipole field $\left(D=180^{\circ}, I=-61^{\circ}\right)$. The scatter of the data from these sites increases significantly at the $5 \%$ significance level after tectonic correction $\left(\mathrm{N}=5, \mathrm{~K}_{1} / \mathrm{K}_{2}=3.9, \mathrm{~F}(8,8) 5 \%\right.$ $=3.44$ ) [McElhinny, 1973]. We thus believe that these sites have been completely remagnetized during a recent reverse period, probably the same one as in the southern zone.

TABLE 1. Paleomagnetic directions from Gargano

\begin{tabular}{lrrrrrrrr}
\hline Site & Age & $\mathrm{n} / \mathrm{N}$ & $\mathrm{D}_{\mathrm{bc}}$ & $\mathrm{I}_{\mathrm{bc}}$ & $\mathrm{D}_{\mathrm{ac}}$ & $\mathrm{I}_{\mathrm{ac}}$ & $\mathrm{K}$ & $\alpha_{95}$ \\
\hline PU39 & 1 & $4 / 8$ & $181^{\circ}$ & $-52^{\circ}$ & $181^{\circ}$ & $-52^{\circ}$ & 281 & 5.5 \\
PU87 & 1 & $16 / 17$ & $299^{\circ}$ & $46^{\circ}$ & $310^{\circ}$ & $50^{\circ}$ & 17 & 9.1 \\
GA19 & 2 & $9 / 21$ & $182^{\circ}$ & $-53^{\circ}$ & $192.5^{\circ}$ & $-59^{\circ}$ & 110 & 5.0 \\
GA20 & 2 & $13 / 14$ & $177^{\circ}$ & $-67^{\circ}$ & $198^{\circ}$ & $-75^{\circ}$ & 170 & 3.2 \\
PU88 & 2 & $8 / 12$ & $179^{\circ}$ & $-59^{\circ}$ & $188^{\circ}$ & $-62^{\circ}$ & 31 & 10.2 \\
GA04 & 3 & $14 / 14$ & $331^{\circ}$ & $47^{\circ}$ & $334^{\circ}$ & $35^{\circ}$ & 207 & 2.8 \\
GA06 & 3 & $9 / 13$ & $167^{\circ}$ & $-58^{\circ}$ & $170^{\circ}$ & $-45^{\circ}$ & 115 & 5.0 \\
GA07 & 3 & $10 / 12$ & $335^{\circ}$ & $52^{\circ}$ & $338^{\circ}$ & $40^{\circ}$ & 174 & 3.7 \\
GA08 & 3 & $10 / 25$ & $171^{\circ}$ & $-60^{\circ}$ & $170^{\circ}$ & $-49^{\circ}$ & 58 & 6.6 \\
GA09 & 3 & $8 / 22$ & $180^{\circ}$ & $-60^{\circ}$ & $187^{\circ}$ & $-49^{\circ}$ & 220 & 3.8 \\
GA11 & 3 & $11 / 27$ & $356^{\circ}$ & $56^{\circ}$ & $358^{\circ}$ & $49^{\circ}$ & 84 & 5.0 \\
GA13 & 3 & $5 / 15$ & $174^{\circ}$ & $-64^{\circ}$ & $174^{\circ}$ & $-54^{\circ}$ & 80 & 9.8 \\
PU38 & 3 & $5 / 10$ & $185^{\circ}$ & $-62^{\circ}$ & $185^{\circ}$ & $-62^{\circ}$ & 76 & 10.1 \\
PU43 & 3 & $5 / 11$ & $345^{\circ}$ & $51^{\circ}$ & $353^{\circ}$ & $55^{\circ}$ & 42 & 13.0 \\
PU79 & 3 & $9 / 9$ & $57^{\circ}$ & $34^{\circ}$ & $11^{\circ}$ & $39^{\circ}$ & 126 & 4.6 \\
PU80 & 3 & $10 / 12$ & $3^{\circ}$ & $50^{\circ}$ & $345^{\circ}$ & $47^{\circ}$ & 51 & 6.9 \\
PU81 & 3 & $5 / 8$ & $161^{\circ}$ & $-43^{\circ}$ & $164^{\circ}$ & $-35^{\circ}$ & 101 & 8.7 \\
PU82 & 3 & $6 / 12$ & $344^{\circ}$ & $55^{\circ}$ & $354^{\circ}$ & $49^{\circ}$ & 29 & 14.0 \\
PU83 & 3 & $7 / 15$ & $1^{\circ}$ & $60^{\circ}$ & $358^{\circ}$ & $49^{\circ}$ & 71 & 7.0 \\
GA01 & 4 & $19 / 20$ & $46.5^{\circ}$ & $33^{\circ}$ & $46.5^{\circ}$ & $33^{\circ}$ & 232 & 2.2 \\
GA02 & 4 & $8 / 8$ & $242^{\circ}$ & $75^{\circ}$ & $242^{\circ}$ & $75^{\circ}$ & 240 & 3.6 \\
\hline & & & & & &
\end{tabular}

Ages: 1-Upper Cretaceous; 2-Lower Eocene; 3-Middle Eocene; 4-Eocene. $\mathrm{n} / \mathrm{N}$ : number of samples giving reliable results/total number of studied samples in the site; declination and inclination are calculated before $\left(\mathrm{Dbc}_{\mathrm{bc}}, \mathrm{I}_{\mathrm{bc}}\right)$ and after $\left(D_{\mathrm{ac}}, \mathrm{I}_{\mathrm{ac}}\right.$ ) bedding correction was applied. 


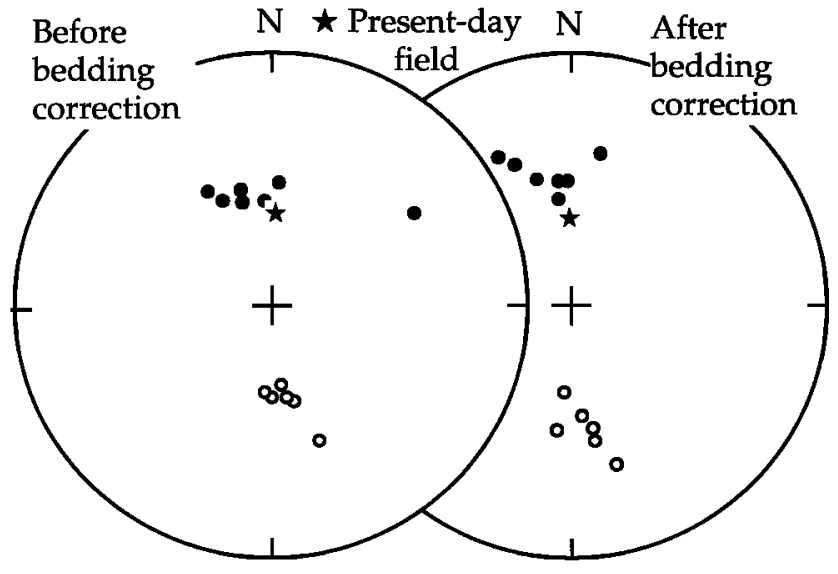

Fig. 4. Equal-area projection of the mean directions of magnetization obtained from Middle-Eocene sites (see zone B in Figure 1) giving reliable results. - downward magnetization directions. O: upward magnetization directions.

Unequivocal conclusions cannot unfortunately be inferred from the 8 normal sites. It is clear from Figure 4 that the mean directions obtained from 7 out of the 8 sites are not significantly different from each other, either before or after tilt correction, although a slight ellipsoidal increase of the scatter can be observed due to the tilt correction. Synfolding remagnetization may be responsible for the increase in the scatter. However, this hypothesis cannot be significantly tested mainly because the studied formations are only slightly tilted. Moreover, both before and after tilt correction, these sites yield a mean regional direction that is close to the present-day geomagnetic field. Therefore the hypothesis of a widespread remagnetization of these sites must be seriously considered. On the other hand, this hypothesis can be ruled out for the eighth site (PU79). Here, the direction before tilt correction is quite different from both the direction of the present-day field and that obtained from the 7 other sites. Upon tilt correction, the direction from this site is rather similar to the tilt-corrected directions from the other ones. Because it exhibits a similar magnetic mineralogy, this would suggest as an alternative hypothesis that also some of the other sites may similarly be not remagnetized. Should this hypothesis be true, the mean regional declination would correspond to a counterclockwise rotation of $11^{\circ} \pm 9^{\circ}$ with respect to the African plate. This rotation is barely significant but, as a mean, it is lower than the angle reported by Lowrie [1986] for the post Cretaceous period. It would indicate that part of the counterclockwise rotation occurred after MiddleEocene time. This result is different from the one obtained for the same period in the Salento [Tozzi et al., 1988] suggesting a large tectonic decoupling between these two zones. However, we must keep in mind that in this last area, the primary character of the magnetization was also uncertain.

Of course, we are well aware that the hypothesis of a nonrotation is highly speculative because it depends on the result obtained from a single site. In order to give a clear cut interpretation, we have also sampled a huge sedimentary slump but, unfortunately the samples were too weakly magnetized. Although a fold test will be difficult to apply in this area because most of the exposures belong to a very slightly tilted monocline, it is clear that further investigations are needed to better establish the primary character of the magnetization in the Eocene platform limestones of Apulia.
Acknowledgments. We wish to thank C. Laj for initiating this study and for helpful discussions and R. Funiciello for his constructive comments and encouragements. M. Tozzi participated in the first part of the sampling, J. Pignatti helped in dating of the studied limestones. The financial support has been given by the French Atomic Energy Commission (CEA) and the University of Rome I. F. Speranza acknowledges a grant from the CEA. This is a C.F.R contribution $n^{\circ} 1407$.

\section{References}

Besse, J. and V. Courtillot, Revised and synthetic Apparent Polar Wander Paths of the African, Eurasian, North American and Indian Plates, and True Polar Wander Since 200 Ma, J. Geophys. Res., 96, 4029-4050, 1991.

Channell, J. E. T., Palaeomagnetism of limestones from the Gargano Peninsula (Italy), and the implication of these data, Geophys. J. R. Astron. Soc., 51, 605-616, 1977.

Channell, J. E. T., B. D'Argenio, and F. Horvath, Adria, the African promontory, in Mesozoic Mediterranean Palaeogeography, Earth Sci. Rev., 15, 213-292, 1979.

Fisher, R. A., Dispersion on a sphere, Proc. R. Soc. 217. 195-305, 1953.

Funiciello, R., P. Montone, F. Salvini, and M. Tozzi, Caratteri strutturali del promontorio del Gargano, Mem. Soc. Geol. It., 41, 1235-1243, 1988.

Lowrie, W., Paleomagnetism and the Adriatic promontory: a reappraisal, Tectonics, 5 (5), 797-807, 1986.

Lowrie, W., Identification of ferromagnetic minerals in a rock by coercitivity and unblocking temperature properties, Geophys. Res. Lett., 17 (2), 159-162, 1990.

McCabe, C., R. Van der Voo, D. R. Peacor, C. R. Scotese, and $R$. Freeman, Diagenetic magnetite carries ancient yet secondary remanence in some Paleozoic sedimentary carbonates, Geology, 11, 221-223, 1983.

McElhinny, M. W., Palaeomagnetism and Plate Tectonics, 358 pp., Cambridge University Press, Cambridge, 1973.

McFadden, P. L. and M. W. McElhinny, The combined analysis of remagnetization circles and direct observations in paleomagnetism, Earth Planet. Sci. Lett., 87, 161-172, 1988.

Ricou, L. E., J. Dercourt, J. Geyssant, C. Grandjacquet, C. Lepvrier, and B. Biju-Duval, Geological constraints on the alpine evolution of the Mediterranean Tethys, Tectonophysics, 123, 83-122, 1986.

Scheepers, P., No tectonic rotation for the Apulia-Gargano foreland in the Pleistocene, Geophys. Res. Lett, 19 (22), 2275-2278, 1992.

Tozzi, M., C. Kissel, R. Funiciello, C. Laj, and M. Parotto, A clockwise rotation of Southern Apulia?, Geophys. Res. Lett., 15 (7), 681-684, 1988.

VandenBerg, J., Reappraisal of paleomagnetic data from Gargano (South Italy), Tectonophysics, 98, 29-41, 1983.

C. Kissel and F. Speranza, Centre des Faibles Radioactivités, Laboratoire mixte CNRS/CEA, Avenue de la Terrasse, 91198 Gif-sur-Yvette Cedex, France.

(Received July 26, 1993; revised August 23, 1993; accepted October 7, 1993.) 